\title{
ANALYSIS OF THE LEVEL OF PREPAREDNESS COMMUNITY OF EARTHQUAKE DISASTERS IN GANGGA SUB-DISTRICT
}

\author{
Apriyatno $^{1}$, Chatarina Muryani ${ }^{2}$, Yasin Yusup ${ }^{3}$, dan Nurhadi ${ }^{4}$ \\ ${ }^{1}$ Geography Education, Universitas Sebelas Maret, Indonesia \\ ${ }^{234}$ Advisor Thesis, Universitas Sebelas Maret, Indonesia \\ Email: apriyatno.shin822@gmail.com
}

\begin{abstract}
Natural conditions and geographical conditions in Indonesia show that natural disasters are very likely to occur. One of the natural disasters that occurred was an earthquake. This research was conducted in the Gangga Sub-district of North Lombok Regency. The main factor in the occurrence of the earthquake which caused many losses was the lack of knowledge regarding the potential and community preparedness for the earthquake disaster. The purpose of this study was to determine the level of community preparedness in dealing with earthquake disasters. The method used is a qualitative method with sampling using cluster random sampling, amounting to 75 respondents. Analysis of community preparedness uses scoring with the help of Geographic Information Systems on four parameters of preparedness, namely knowledge and attitudes, emergency response plans, disaster warning systems, and resource mobilization. The results of this study are Gangga Sub-district community preparedness is divided into two categories, namely middle preparedness, and high preparedness categories. The category of preparedness is currently found in Bentek, Genggelang, and Rempek villages. Meanwhile, the category of high preparedness is found in Gondang village and Sambik Bangkol village. Bearing in mind that the Gangga Sub-district is an earthquake-prone area, it is expected that the government, family, and community will be able to improve preparedness so that the community can live better in earthquake-prone areas.
\end{abstract}

Keywords: Disaster, Preparedness, Society, Earthquake

\section{A. INTRODUCTION}

According to Setiawan (2014) Indonesia is a country rings of fire in the world because it is surrounded by rows of active mountains from west to east. Therefore various phenomena such as earthquakes and volcanic eruptions often occur in Indonesia (in; (Hermon, 2015). Earthquakes are vibrations or shocks that occur and are felt on the surface of the earth originating from the earth's structure. the sudden release of seismic wave energy caused by tectonic plate deformation that occurs in the earth's crust (Christanto, 2011).
West Nusa Tenggara consists of Lombok Island and Sumbawa Island which have an area of $20,164.84 \mathrm{~km}^{2}$. Located between $115^{0} 46^{\prime}-119^{0} 5^{\prime} \mathrm{BT}$ and $8^{0} 10^{\prime}-$ $9^{0} \quad 5^{\prime} \quad$ LS. The West Nusa Tenggara Province has a population of $4.99,578$ people with a total number of households of 1,376,934 households with a population growth rate of $1.36 \%$ per year. From an economic perspective, the percentage of poor people in West Nusa Tenggara Province was $16.07 \%$ or around 793,776 people in 2017 with a poverty line in the 
month of March 2017 amounted to 345.34 people (BPS, 2018).

The low level of economic and public education has more potential to experience a greater impact due to the earthquake disaster. The weak understanding of the community about the dangers of natural disasters that occur as well as the ability to survive and recover in anticipating disasters makes the community vulnerable to earthquakes. Apart from the education aspect of the community, the mindset of the people who are already semi-modern is marked by the construction of modern residential houses, while many modern houses built in the area around the earthquake many are badly damaged because the building is not resistant to earthquakes. The incident caused the people who live around the area affected by the earthquake to be vulnerable to similar incidents or post-earthquake events.

Law Number 24 of 2007 concerning disaster management explains that preparedness is a series of activities carried out to anticipate disasters through organizing as well as through appropriate and efficient steps (Undang-Undang Nomor 24, 2007). According to (Matsuda, 2006) disaster preparedness is observed as a participatory community management process, where participating agents are expected to share knowledge. According to the Charter in (UNESCO/ ISDR, 2006) defines disaster preparedness as actions that enable governments, organizations, communities, and individuals to be able to respond to a disaster situation quickly and efficiently. According to Drabek (1986) Disaster preparedness is the most important stage before the occurrence of a disaster because it increases the capacity of individual, household or community response to disasters and, therefore, minimizes the disturbing and dangerous impacts associated with these events (Drabek, 1986). This is in accordance with the statement (Bevaola, 2014), citing Gillespie and Streeter defining preparedness as planning, resource identification, warning systems, training simulation, and pre-disaster actions others were taken to the main purpose of improving the safety and effectiveness of public response during a disaster.

Countries that are vulnerable to natural hazards have anticipated consequences and effects, thereby encouraging disaster management and risk reduction to reduce risk and facilitate recovery from these hazards in the event of a disaster. For hazards that occur without warning, mitigation initiatives and preparedness are far more important. In addition, developing the ability to mobilize preparedness plans quickly and effectively requires efforts to face challenges such as 
how people understand hazards, interpret risks, and the extent to which people are prepared to prepare for disasters (Paton, D., Johnston, 2015).

Research related to community preparedness conducted in the Port of Teluk Ratu area by Chrisantum (2011), shows the results that the community is not ready to face the threat of the tsunami disaster, among others because many people do not know the vulnerability of their area to disaster (Chrisantum Aji Pramesti, 2011). Other research related to preparedness conducted by Nuno Martins, Joane Nigg, Hans M Louis-Charles, and James M. Kendra (2018) states that preparedness at the household level, the unit of analysis includes: gathering information related to disasters; attend meetings on disaster preparation; buy food and water; has a flashlight, radio, battery, and first aid kit; developing family emergency plans; do the exercises; learn first aid; secure furniture; and the acquisition of hazard insurance (Martins, Nigg, Louis-charles, Kendra, \& Sandy, 2018). Many factors shape community preparedness, ranging from knowledge and attitudes, policies, emergency response plans, disaster warning systems, and resource mobilization. Education also has a significant influence. Individuals with higher levels of education have, in theory, better and more professional opportunities
(Morrow, 1999). Preparedness is carried out before a disaster event which is directed to the situation when a disaster occurs in order to avoid the number of victims, property losses and changes in people's lives.

Based on the description and presentation above, the research problem is "what is the level of community preparedness in dealing with earthquake disasters in the Gangga Sub-district". The purpose of this study was to determine the level of preparedness community in dealing with an earthquake in the Gangga Sub-district, North Lombok Regency, including knowledge and attitudes, emergency response plans, disaster warning systems, and resource mobilization.

\section{B. MATERIALS AND METHODS}

This study was conducted in the Gangga Sub-district, North Lombok Regency. The method used in this study is a qualitative method with sampling using cluster random sampling, amounting to 75 respondents. Analysis of community preparedness uses scoring with the help of Geographic Information Systems on four parameters of preparedness, namely knowledge and attitudes, emergency response plans, disaster warning systems, and resource mobilization. The research location can be seen in Figure 1 as follows: 


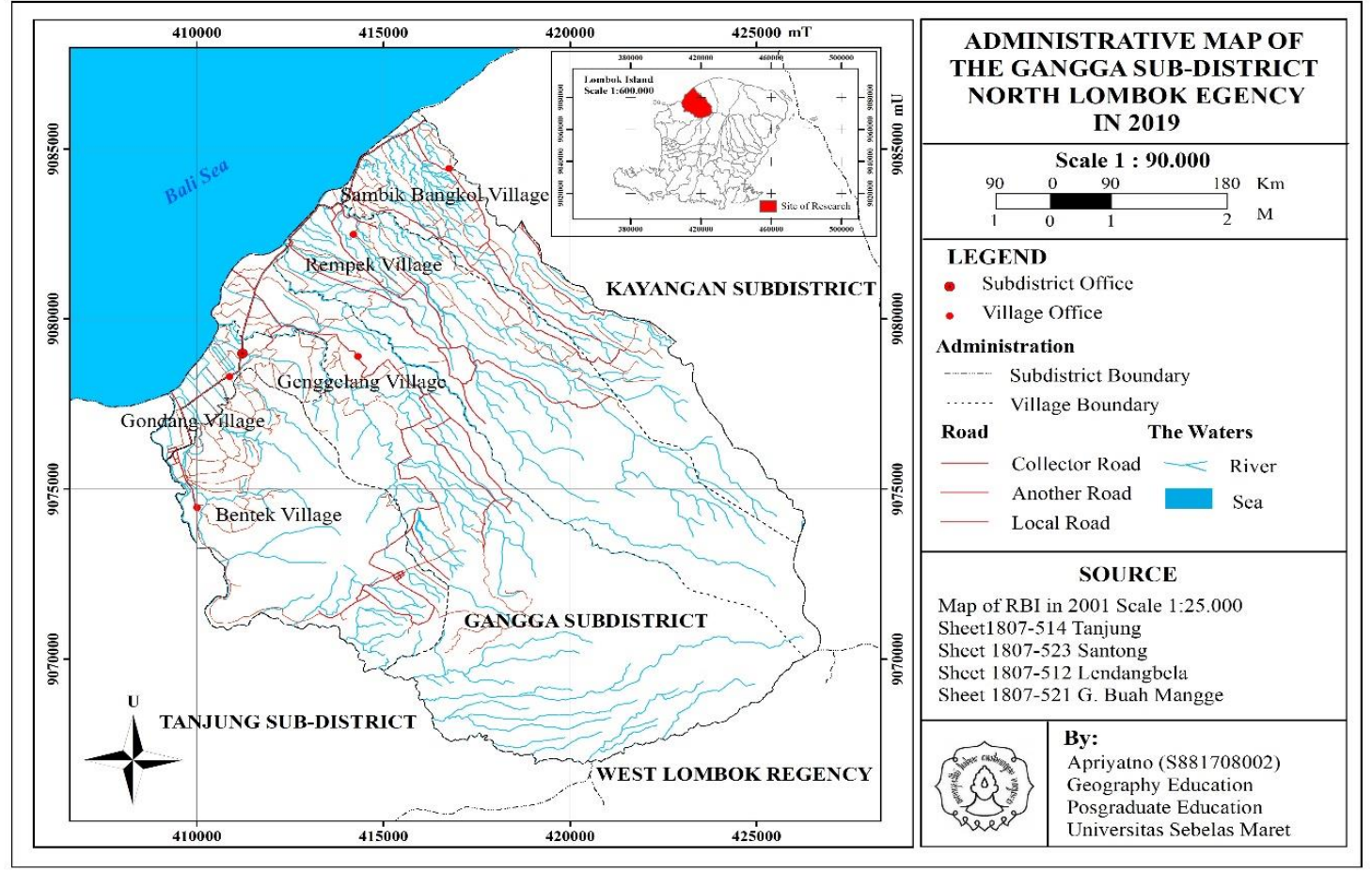

Figure 1. Research Location Map in Gangga Sub-district

Source: Researcher, 2019

\section{Parameters Index}

The Index is calculated based on the results of the questionnaire calculations given by respondents on each parameter. The parameter index includes knowledge of attitudes, policies, and guidelines, plans for emergencies, disaster warning systems, resource mobilization. The index per parameter for individualhouseholds using the combined index is not weighted, meaning that each question on the questionnaire has the same weight.

The level of disaster preparedness can be determined by calculating by scoring or evaluating respondents' answers. If the respondent's answer is "yes / done" then the score is 1 and if the respondent's answer is "no / not done" then the score is 0 (Guttman Scale) (Sugiyono, 2014).

Index $=\frac{\text { Total Score Real Parameters }}{\text { Score Maximum Parameters }} \times 100$

a. Knowledge and Attitude

$$
\text { Index }=\frac{\sum}{4} x 100
$$

b. Emergency Response Plan

$$
\text { Index }=\frac{\sum}{4} x 100
$$

c. Disaster Management Parameters

$$
\text { Index }=\frac{\sum}{4} x 100
$$

d. Resource Mobilization Parameters

$$
\text { Index }=\frac{\sum}{4} x 100
$$


2. Index Combined

Composite Index is of some parameters collected using the weighted composite index. So each parameter has a different weight. Community preparedness can be calculated using the following formula:

$=0,25 \mathrm{x}$ Index $\mathrm{KA}+0,25 \mathrm{x}$ Index EP + $0,25 \times$ Index WS + 0,25 x Indeks RMC

Information:

KA : Knowledge and Attitude

EP : Emergency Response Plan

WS : Disaster Warning

RMC : Resource Mobilization

If the number of samples is $n$, then the overall sample index can be calculated by summing the sample index divided by the number of samples (n), after calculating the preparedness index, then the next value is matched with the table below. Table 1 Index of Community Preparedness Level

\begin{tabular}{ccc}
\hline No & Index Score & Category \\
\hline $\mathbf{1}$ & $80-100$ & Very High \\
\hline $\mathbf{2}$ & $65-79$ & High \\
\hline $\mathbf{3}$ & $55-64$ & Middle \\
\hline $\mathbf{4}$ & $40-54$ & Low \\
\hline $\mathbf{5}$ & $<40$ & Very Low
\end{tabular}

Source: LIPI-UNESCO / ISDR, 2006 with modification

\section{RESULTS AND DISCUSSION}

Gangga Sub-district is one of the sub-districts in the North Lombok Regency whose territory is potentially affected by an earthquake due to its location located right above active faults that resulted in the movement of Lempeng earth. Administratively, the Gangga sub-district is divided into five villages, namely Bentek Village, Gondang Village, Genggelang Village, Rempek Village, and Sambik Bangkol Village.

Community preparedness in dealing with earthquakes can be measured using preparedness parameters by using the LIPI-UNESCO / ISDR guideline for 2006. There are five parameters used to measure the level of preparedness, namely; Knowledge and Attitudes / Knowledge and Attitude (KA), the Emergency Response Plan / Emergency Planning (EP), Disaster Warning System / Warning System (WS), and Resource Mobilization / Resource Mobilization Capacity (RMC).

The level of community preparedness can be determined through the calculation of the preparedness index obtained from the results of a questionnaire score that has been distributed to each respondent in each village that is the location of the study. The preparation of instrument questions 
based on these preparedness parameters each parameter contained 5 items. Based on data obtained in the field, the following are the results of the preparedness index calculation for each village in the Gangga Sub-district.
After knowing the per-parameter index, the total index is obtained. The total community index value obtained results presented in Table 2 and Figure 2 as follows.

Table 2 Total Community Preparedness Index

\begin{tabular}{|c|c|c|c|c|c|c|c|}
\hline \multirow{2}{*}{ No } & \multirow{2}{*}{ Village } & \multicolumn{4}{|c|}{ Preparedness Parameters } & \multirow{2}{*}{ Total Index } & \multirow{2}{*}{ Category } \\
\hline & & KA & EP & WS & RMC & & \\
\hline 1 & Bentek & 16 & 13,67 & 13,67 & 15,33 & 58,67 & Middle \\
\hline 2 & Gondang & 20,33 & 15 & 16 & 15,67 & 67 & High \\
\hline 3 & Genggelang & 14,33 & 16,33 & 13,33 & 13,33 & 57,32 & Middle \\
\hline 4 & Rempek & 14,33 & 13,67 & 13,33 & 14,67 & 56 & Middle \\
\hline 5 & Sambik Bangkol & 17,33 & 20 & 14,33 & 19 & 70,67 & High \\
\hline
\end{tabular}

Source: Data Processing, 2019

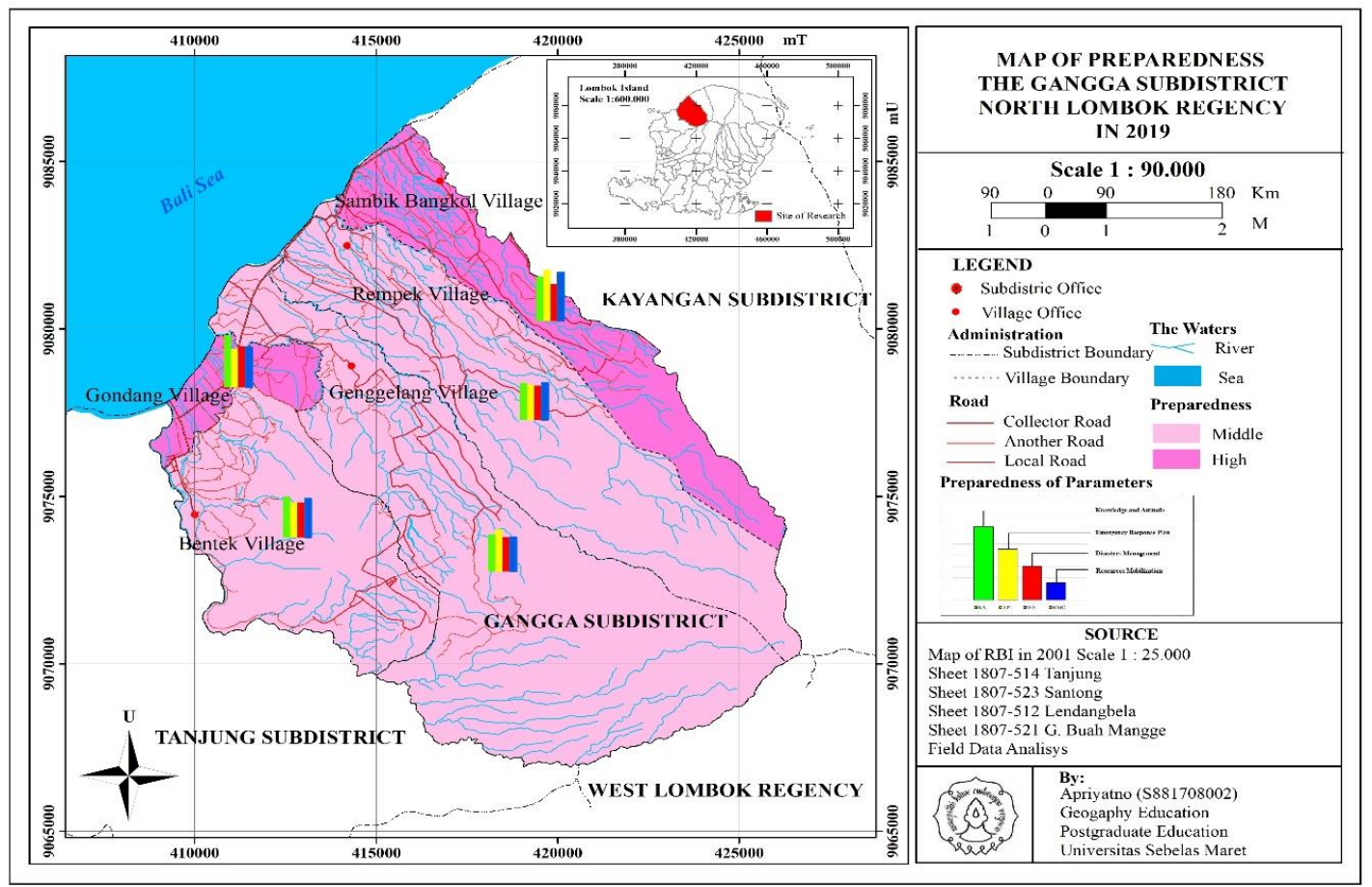

Figure 1. Research Location Map in Gangga Sub-district Source: Researcher, 2019 
Based on Table 2, overall, of the four community preparedness measurement parameters, the parameter that has the lowest parameters is the disaster warning system which occurred in all four villages in the Gangga sub-district, and one parameter for the emergency response plan in Gondang village. In the village including the community preparedness category being the Village Bentek total index value of 58.67, with Genggelang Village total index of 57.32, and the Village Rempek total index value of 56. These three villages have the lowest score on the parameter disaster warning system. This parameter concerns warnings made by the community when an earthquake disaster occurs. The earthquake that struck their area of residence happened suddenly so that the community did not have time to try to save themselves. The important point of this parameter is the existence of clear sources of information that can be used by the community. Meanwhile, Gondang Village had the lowest value on the parameters of the emergency response plan with a score of 15 . This was because most of the community still lacked P3K equipment and important telephone numbers used to communicate.

The preparedness index with the highest index value is a parameter knowledge and attitude in Gondang Village with a score of 20.33 and Sambik
Bangkol Village with a score of 17.33, emergency response plan in Genggelang Village with a score of 16.33 and Sambik Bangkol Village with a score of 20, and Mobilization Resources in Sambik Bangkol Village with a score of 19. In the knowledge and attitude parameters emphasize how the community knows the location of a residence that has the potential to experience an earthquake so that it can be used as learning in the event of a disaster in the future because the community has understood and given socialization from the government related to disaster simulation. Based on the results of interviews in the field, the researchers concluded that the people of Gondang Village and Sambik Bangkol Village had indeed understood and understood the potential of disasters in their homes. The parameters of the emergency response plan put more emphasis on actions when experiencing a disaster event, such as the availability of first aid kits for first aid, alternative communication tools in the event of a disaster, as well as materials for dealing with disasters. Meanwhile, the preparedness parameter with the other highest index value is the resource mobilization parameter. This parameter is called on the community attend preparedness training so that they are alert when natural disasters occur, social 
networks and disaster anticipations take the form of allocating public funds.

Basically, preparedness is an initial capital used by humans in the face of a disaster such as an earthquake. For this reason, it is necessary to understand and understand disaster-related to potential disasters that may occur at the location of residence. (Mokhtar, K. S \& Lateh, 2012) stated that the level of education had a significant impact on the parameters of knowledge and attitudes. In addition, the type of settlement also determines because different locations of residence provide different perspectives on a disaster. This is the same as what happened in the Gangga Sub-district, where the community was prepared to face the earthquake disaster. Mindset and educational background determine people's behavior toward nature. However, the level of education is not always a major factor because there are still economic factors that can also determine the behavior of the surrounding environment.

The earthquake that occurred in Gangga Sub-district was used by the community as a lesson learned from the disaster as well as providing knowledge to the community so that they were aware of the potential for earthquakes in their neighborhoods. Preparedness makes the community more alert and considers all actions so that they are not at risk from the disaster (Dodon, 2013). Research conducted by Kim and Kang (2010) determined that the bonds made by households with their communities had no effect on their storm preparedness. Given the conflicting conclusions about the role of social capital in preparedness, it is important to assess the implications of social capital in household protection behavior before the impending disaster (Y. C. Kim and J. Kang, 2010). For this reason, the level of community preparedness will increase when they are faced with similar disasters in the future because they have mirrored their previous experiences so that the community knows what actions should be taken to avoid the risk of the impact of a disaster.

\section{CONCLUSIONS}

Community preparedness for earthquake disasters in the District of Gangga is included in the category of moderate preparedness, there are two villages which are categorized as high preparedness namely Gondang Village with a total index of 67 and Sambik Bangkol Village with a total index of 70.67. Whereas three villages are included in the middle preparedness category, namely Bentek Village with a total index of 58.67, Genggelang Village with a total index of 57.32, and Rempek Village with a total index of 56 . Overall the level of 
community preparedness in the Gangga

Sub-district of North Lombok Regency is included in the "Category Middle".

\section{E. ACKNOWLEDGMENTS}

Thanks, the Author conveys to parents, community Gangga Sub-district which has made it easier and gives permission in this study. Thank you, Prof. Dr. Chatarina Muryani, M.Si., Dr. Yasin Yusup, M.Si., and Dr. rer.nat Nurhadi, S.Ant., M.Hum. as a thesis advisor at the Geography Education Masters Program, Universitas Sebelas Maret.

\section{F. REFERENCES}

Bevaola, K. (2014). Manajemen Bencana dan Kapabilitas Pemerintah Lokal. Yogyakarta: Gava Media.

BPS. (2018). Nusa Tenggara Barat Dalam Angka. Badan Pusat Statistik.

Chrisantum Aji Pramesti. (2011). Kesiapsiagaan Masyarakat Kawasan Teluk Pelabuhan Ratu Terhadap Bencana Gempa Bumi dan Tsunami. Jurnal Perencanaan Wilayah Dan Kota, 22(2), 113-128.

Christanto, J. (2011). Gempa Bumi, Kerusakan Lingkungan, Kebijakan dan Strategi Pengelolaan. Yogyakarta: Pustaka Pelajar.

Dodon. (2013). Indikator dan Perilaku Kesiapsiagaan Masyarakat di Permukiman Padat Penduduk dalam Antisipasi Berbagai Fase Bencana Banjir. Jurnal Perencanaan Wilayah Dan Kota, 24(2), 125-140.

Drabek, T. (1986). Human System Responses to Disasters: An Inventory of Sociological Findings. New York:
Springer-Verlag.

Hermon, D. (2015). Geografi Bencana Alam. Jakarta: Rajawali Press.

Martins, V. N., Nigg, J., Louis-charles, H. M., Kendra, J. M., \& Sandy, S. (2018). International Journal of Disaster Risk Reduction Household preparedness in an imminent disaster threat scenario: The case of superstorm sandy in New York City. International Journal of Disaster Risk Reduction, (October), 1-10. https://doi.org/10.1016/j.ijdrr.2018.1 1.003

Matsuda, et. a. (2006). Community Diagnosis for Sustainable Disaster Preparedness. Journal Natural Disaster Science, 28, 25-33.

Mokhtar, K. S \& Lateh, H. (2012). Towards Community-Based Landslide Preparedness in Malaysia. ISQR Journal of Environmental Science, Toxicology, and Food Technology, 1-9.

Morrow, B. H. (1999). Identifying and Mapping Community Vulnerability. Disasters, 23(1), 11-18.

Paton, D., Johnston, D. (2015). The Christchurch Earthquake: Integrating Perspectives From Diverse Disciplines. International Journal of Disaster Risk Reduction, 14(1), 1-5.

Sugiyono. (2014). Memahami Penelitian Kualitatif. Bandung: Alfabeta.

Undang-Undang Nomor 24 (2007). Retrieved from Tentang Penanggulangan Bencana

UNESCO/ ISDR, L. (2006). Kajian Kesiapsiagaan masyarakat dalam Menghadapi Ancaman Bencana Alam. Jakarta: LIPI Press.

Y. C. Kim and J. Kang. (2010). Communication, Neighborhood Belonging and Hurricane Preparedness. Disasters, 34(2), 470488. 